\title{
Decadal Changes in the Ocean Climate in Newfoundland and Labrador Waters from the 1950s to the 1990s
}

\author{
E. B. Colbourne \\ Northwest Atlantic Fisheries Centre, P. O. Box 5667, St. John's, NL A1C 5X1
}

Colbourne, E. B. 2004. Decadal Changes in the Ocean Climate in Newfoundland and Labrador Waters from the 1950s to the 1990s. 2004. J. Northw. Atl. Fish. Sci., 34: 43-61. doi:10.2960/J.v34.m478

\begin{abstract}
A review of decadal changes in the ocean climate in NAFO waters adjacent to Newfoundland and Labrador is presented based on standard station and section data and data from fishery resource assessment surveys. Both the annual trends and decadal means are examined for the decades of the 1950 s to the $1990 \mathrm{~s}$. The analysis indicates that the 1950 s and particularly the 1960 s were the warmest decades during the latter half of the $20^{\text {th }}$ century and the 1990 s represent the third consecutive decade with below normal temperatures on the Newfoundland Shelf. The decadal mean salinity indicate that the magnitude of negative salinity anomaly on the inner Newfoundland Shelf during the 1990s was comparable to that experienced during the 'Great Salinity Anomaly' of the early 1970s. In addition, the decade of the 1990s has experienced some of the most extreme variations since measurements began during the mid-1940s. Ocean temperatures ranged from record low values during 1991 to record highs during 1999 in many areas, particularly on the Grand Bank of Newfoundland. The potential impact of the changes in ocean climate during the past several decades on marine production in Newfoundland waters is discussed.
\end{abstract}

Key words: decadal means, interdecadal, Newfoundland shelf, ocean climate, temperature, salinity.

\section{Introduction}

The latter half of the $20^{\text {th }}$ century has been a period of considerable variability in the physical environment on the Newfoundland Shelf. During the decades of the 1950s and 1960s the ocean environment was dominated by a general warming phase that reached its maximum by the mid- to-late 1960s. Beginning in the early 1970s, however, climate conditions in the Northwest Atlantic experienced near-decadal oscillations, with a general downward trend in ocean temperatures (Colbourne et al., 1994; Drinkwater, 1996). During the most recent decade (1990s) the Northwest Atlantic experienced some of the most extreme variations in ocean conditions since measurements began in the mid-1940s (Colbourne, MS 2001; Drinkwater et al., MS 2001; Colbourne and Anderson, 2003).

Recognizing the potential importance of ocean climate in determining the distribution and abundance of marine organisms, the International Commission for the Northwest Atlantic Fisheries (ICNAF) initiated a series of symposia aimed at reviewing variations in the ocean environment on decadal time scales (ICNAF, 1967; 1972; NAFO, 1982; 1994). The most recent reviews, including the current one, were conducted by the Standing Committee on Fisheries Environment (STACFEN) of the
Northwest Atlantic Fisheries Organization (NAFO). In this manuscript environmental conditions in the Northwest Atlantic for the decade of the 1990s are examined in relation to the previous decades. The long-term trends in the physical environment since the 1950s are first reviewed and the mean conditions on decadal time scales are then examined. Finally, variations within the decade of the 1990s are presented in more detail followed by a brief summary of climate conditions and their possible impact on marine production in Newfoundland and Labrador waters.

\section{Data and Methods}

The data utilized in this paper were obtained from several sources. The most spatially comprehensive oceanographic data sets for the Newfoundland Shelf are from the spring and autumn stratified random ground fish trawl surveys conducted by the Canadian Department of Fisheries and Oceans. Canada has been conducting these surveys in NAFO Divisions 2J3KLNO since the early-1970s (Doubleday, 1981; Bishop, MS 1994). Oceanographic data were collected during the surveys at most fishing locations, either by bathythermographs (mechanical and expendable MBT/XBT) in the earlier years or by trawl-mounted conductivity-temperaturedepth recorders (CTDs) during the 1990s. 
Annual and seasonal oceanographic monitoring surveys along standard sections on the Newfoundland Shelf were initiated by the International Ice Patrol of the US Coast Guard soon after the Titanic disaster in 1912 to monitor variations in the Labrador Current. Since the 1940s, oceanographic data were collected on research surveys along standardized sections (Fig. 1) under the auspices of the International Commission for Northwest Atlantic Fisheries by several countries and currently for the Northwest Atlantic Fisheries Organization. Additionally, as part of an expanded Canadian Atlantic zone oceanographic monitoring program, some of these sections are now sampled on a seasonal basis (Therriault et al., 1998).

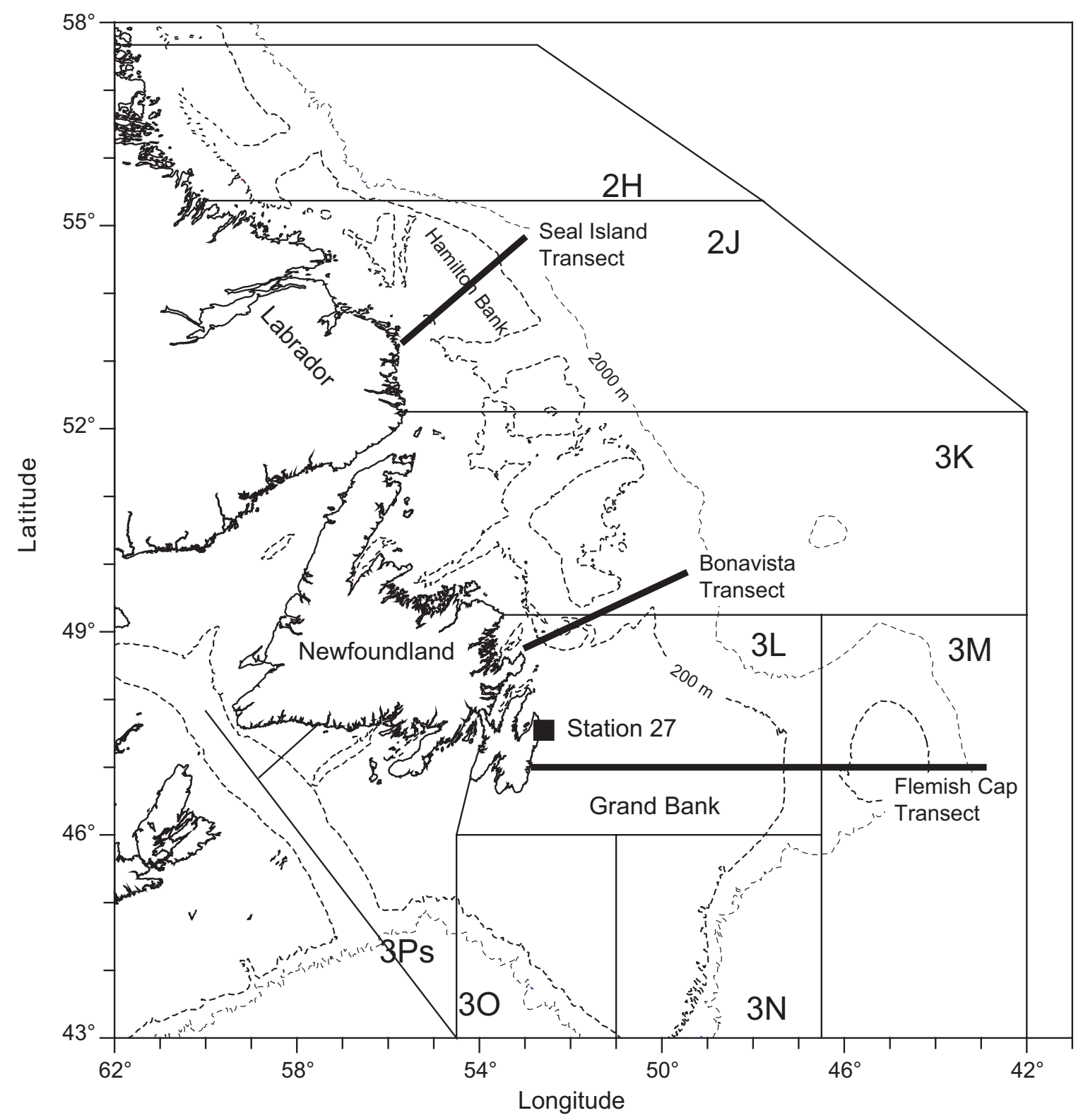

Fig. 1. Regional map showing the positions of standard monitoring sections, Station 27 and the statistical fish management areas established by the Northwest Atlantic Fisheries Organisation (NAFO). 
Collectively, these surveys provided a comprehensive oceanographic data set for the Newfoundland Shelf region with good temporal and spatial coverage for most of the decades since the 1950s. In this paper we present some of the environmental time series as differences from their long-term averages (anomalies) referenced to a standardised base period from 1961-90 (normal) in accordance with the convention of the World Meteorological Organisation and recommendations of the NAFO scientific council. Oceanographic data from other available sources archived at the Marine Environmental Data Service (MEDS) in Ottawa were also used to define long-term means. The decadal means computed here are for the years 1961-70, 1971-80, 1981-90 and 1991-2000.

\section{Results}

\section{Background}

The ocean circulation in the Northwest Atlantic has been described many times (Smith et al., 1937; Peterson, 1987; Greenberg and Petrie, 1988; Chapman and Beardsley, 1989; Lazier and Wright 1993; Petrie and Anderson, 1983; Drinkwater, 1996 and Colbourne et al., 1997a). The following brief discussion summarizes the main ocean current features influencing the Newfoundland and Labrador Shelf region.

The main components of the large-scale circulation consist of the West Greenland Current, which flows northward along the West Coast of Greenland. A branch of this flow turns westward and crosses the northern Labrador Sea forming the northern section of the northwest Atlantic sub-polar gyre. Near the northern tip of Labrador, outflow through Hudson Strait combines with the east Baffin Island Current and flows southeastward along the Labrador coast as a strong western boundary current known as the Labrador Current. The flow over the shelf is strongly influenced by the seabed topography, following the various cross shelf saddles and inshore troughs. A well-defined inshore branch has formed by the time the flow reaches the mid-Labrador Shelf. Most of the volume transport however, remains offshore at the edge of the continental shelf centered mainly over the 400-1 $200 \mathrm{~m}$ isobaths (Lazier and Wright, 1993).

Further south, near the northern Grand Bank, the inshore branch becomes broader and less defined. In this region, most of the inshore flow combines with the offshore branch and flows eastward. The major portion follows the bathymetry southward around the southeast Grand Bank although a smaller portion flows farther eastward and then southward around the Flemish Cap. The remainder of the inshore branch flows through the
Avalon Channel, around the Avalon Peninsula, and then westward along the Newfoundland south coast. Off the southern Grand Bank the offshore branch flows westward along the continental slope where it is influenced by the Gulf Stream and slope waters, into the Laurentian Channel and eventually enters the Gulf of St. Lawrence (Hachey et al., 1954). Additionally, part of the flow combines with the North Atlantic Current and forms the southern section of the sub-polar gyre. Within this large complex circulation system the Labrador Current is the most important feature influencing the Newfoundland Shelf area, advecting cold, relatively fresh, polar water together with sea-ice and icebergs from the Arctic to lower latitudes along the Labrador Coast to the Grand Bank regions. In some years these Arctic waters can be traced as far south as the Middle Atlantic Bight in NAFO Subareas 5 and 6.

Seasonal variations in atmospheric forcing (e.g., air temperatures and wind stress) and sea-ice extent lead to strong annual cycles in the water mass properties (Petrie et al., 1991) with intense horizontal and vertical gradients, particularly on the continental shelf regions of Newfoundland and Labrador. Interannual changes in these forces, coupled with changing advection patterns, are responsible for variations in the ocean climate on the Newfoundland Shelf. In particular, the strength of the cyclonic atmospheric circulation over the North Atlantic, especially during the winter months, influences sea-ice conditions, ocean temperatures and shelf stratification particularly in NAFO Subarea 2 (Colbourne et al., 1994; Drinkwater, 1996).

A standard meteorological index representing the strength of the winter atmospheric circulation has been termed the North Atlantic Oscillation (NAO) index and is defined as the difference in the winter sea-level air pressure between the quasi-stationary winter high and low pressure cells over the Azores and Iceland, respectively (Rogers, 1984). During decades when the NAO index is predominately negative, warm and generally saline ocean conditions prevail in the Northwest Atlantic and colder-fresher conditions predominate in the Northeast Atlantic; and conversely when the NAO index is high positive. Spatial variations in the positions and extent of the pressure cells sometimes result in significant inter-annual variations in the strength of the winter wind patterns in any one location. Overall however, the decadal changes in the NAO are significantly correlated with ocean climate variability in the Northwest Atlantic including the Newfoundland Shelf(Colbourne et al., 1994; Drinkwater, 1996; Colbourne and Anderson, 2003). In the next section, the long-term variability in various ocean climate indices derived from the data sets described above is reviewed on decadal time scales. 


\section{Inter-Decadal Variability}

Temperature and Salinity. Ocean temperatures and salinity have been measured routinely during the past five decades at a standard hydrographic monitoring station (Station 27, Fig. 1) located in the inshore branch of the Labrador Current on the inner Newfoundland Continental Shelf (Huyer and Verney, 1975; Keeley, 1981; Colbourne and Fitzpatrick, 1994). This inshore site is representative of ocean conditions over a wide area of the Newfoundland Shelf down to a water depth of $176 \mathrm{~m}$ (Petrie et al., 1991). Temperature anomalies at most depths at this site were predominately above normal during the decades of the 1950s and 1960s, reaching their maximum values by the late 1960s. After the late 1960s temperatures declined steadily, reaching near-record low values by the early 1970s before increasing to above normal values from the mid-to-late 1970s and early 1980s. After about 1982, temperatures again declined to below normal, reaching a record low in 1991 in the upper water column. Near-bottom temperatures remained below normal until around 1996, the longest period of belownormal temperatures in the 50-year record (Fig. 2). The decadal mean temperatures also displayed in Fig. 2 show that the 1950s and particularly the 1960s were the warmest decades during the latter half of the $20^{\text {th }}$ century and the 1990s represent the third consecutive decade with below normal temperatures. During the decades of the 1970s, 1980s and 1990s temperatures were below normal over the whole water column on the inner Newfoundland Shelf, with the largest anomalies occurring in the top $50 \mathrm{~m}$ of the water column.

Salinity anomalies in the upper $50 \mathrm{~m}$ of the water column during the decade of the 1950s varied about the normal but increased to above normal values during most of the 1960s before declining to very low values during the late-1960s and early 1970s (Fig. 2). Since then the time series is dominated by three salinity minima, in the early-1970s, early- to-mid 1980s and most of the 1990s. In water depths generally below $50 \mathrm{~m}$, the patterns were very similar, but the variations were of a much smaller magnitude. In general, during these three decades cold ocean temperatures and lower-than-normal salinities were associated with strong positive NAO index anomalies, colder-than-normal winter air temperatures, heavy ice conditions and larger than normal volumes of $<0^{\circ} \mathrm{C}$ water on the Newfoundland Shelf (Colbourne et al., 1994; Drinkwater, 1996). The decadal mean salinities also displayed in Fig. 2 show that during the 1950s salinities were below normal except near bottom and during the decades of the 1960s-1980s the signs of the salinity anomalies were depth dependent. During the decade of the 1990s however, salinities were significantly lower-than-normal over all depth ranges, with the largest anomaly in the surface waters. The longest single period of fresher-than-normal salinities on record occurred during the 1990s (Fig. 2).

Two of the most widely used indices of ocean climate for Newfoundland waters have been the annual vertically-averaged temperature and summer upper-layer averaged salinity. The vertically averaged temperature is proportional to the total heat content of the water column while the upper layer average summer salinity is a measure of the magnitude of the freshwater pulse from melting sea ice on the Labrador Shelf (Myers et al., 1990). The temperature time series shows large amplitude fluctuations at near-decadal time scale, with cold periods during the early-1970s, mid-1980s and early-1990s. From 1950 to the late 1960s the heat content of the water column was generally above the long-term mean. It reached a record low during 1991, a near-record high during 1996, near normal in 1997 and 1998 and above normal during 1999-2000 (Fig. 3). The decadal mean water column temperatures also displayed in Fig. 3 show that the 1950s and the 1960s were warmer-than-normal and the decades of the 1970s, 1980s and 1990s were all periods with below normal oceanic heat content on the Newfoundland Shelf. Except for the 1960s all decades exhibit similar variability with the decades of the 1950s and 1960s significantly warmer than the past three decades at the one standard error level (68\%).

The salinity data (Fig. 3) show similar trends as temperature, with fresher-than-normal periods generally corresponding to the colder-than-normal conditions up to at least the early-1990s, although the phase of the salinity cycle preceded that of temperature by approximately five years in the late 1960s. Since then the phase difference generally changed over the time series, decreasing to one to two years from the late 1970s to early-1990s. The predominance of fresher-than-normal salinities during the latter half of the 1990s corresponding to a significant warming trend is notable. The decadal mean salinities (Fig. 3) indicate that the magnitude of the negative salinity anomaly on the Newfoundland Shelf during the early-1990s was comparable to or even exceeded that experienced during the 'Great Salinity Anomaly' of the early-1970s (Dickson et al., 1988). However, the fresh water was mostly restricted to the shelf regions during the 1990s, unlike the 1970s when it extended throughout much of the Northwest Atlantic (Dickson et al., 1988; Myers et al., 1989; Colbourne, 2000). Also both the 1970s and 1990 s were significantly fresher then the 1960s and 1980s at the one standard error confidence level (68\%). 

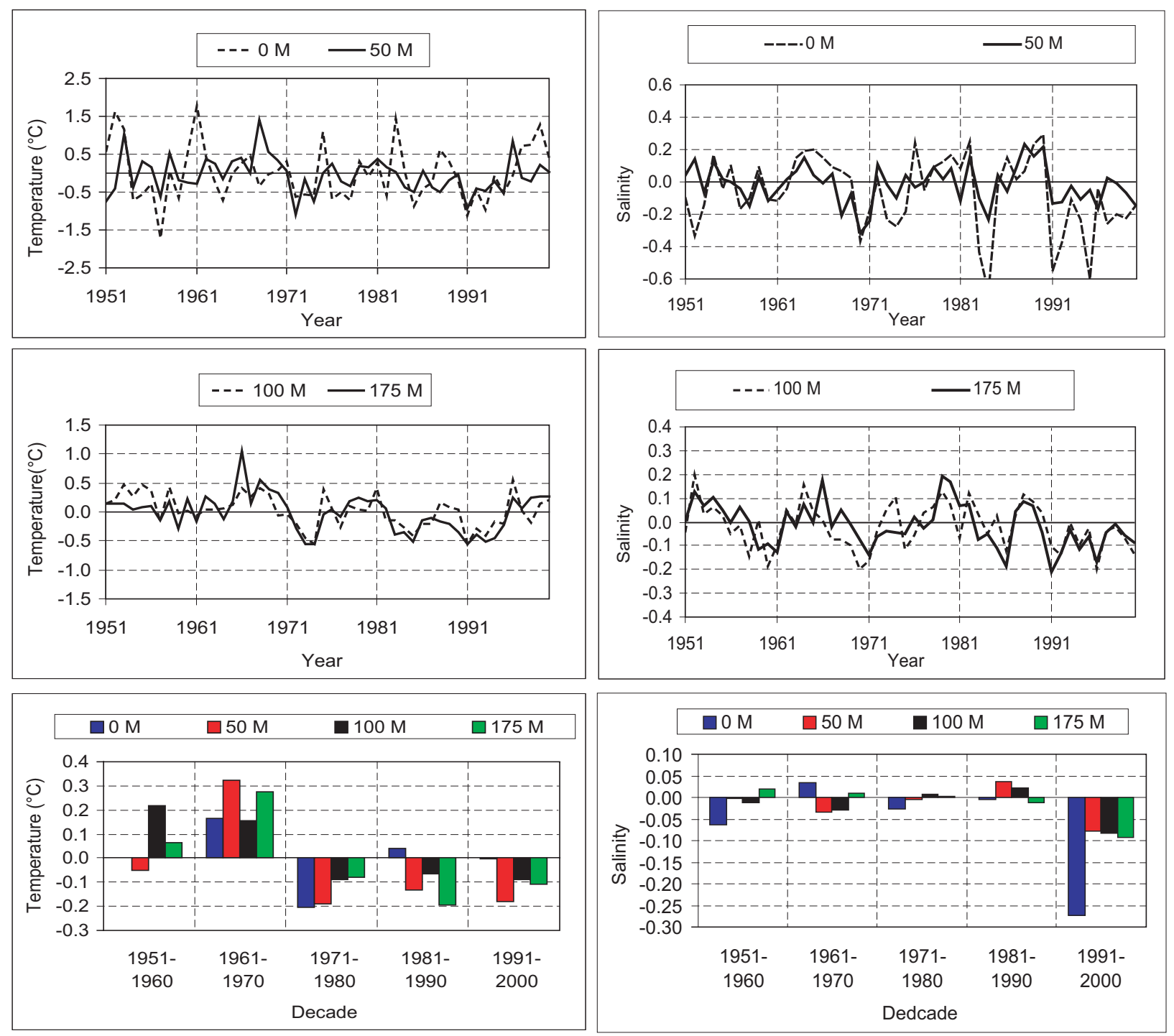

Fig. 2. Station 27 annual temperature and salinity anomalies at selected depths (top panels) and their decadal means (bottom panels).

Standard Sections. In 1976 the International Commission for the Northwest Atlantic Fisheries officially adopted a suite of standard oceanographic monitoring stations along sections in the Northwest Atlantic Ocean from Cape Cod (USA) to Egdesminde (West Greenland) (ICNAF, 1978). The Canadian Department of Fisheries and Oceans samples several of these sections during a mid-summer annual oceanographic survey. The most consistently sampled include the Seal Island section on the southern Labrador Shelf, the Bonavista section off the east coast of Newfoundland and the Flemish Cap section that crosses the Grand Bank at $47^{\circ} \mathrm{N}$ and continues eastward across the Flemish Cap (Fig. 1).

The most striking feature of the summer temperature structure on the Newfoundland Shelf from the standard sections is the large volume of sub-surface water with temperatures ranging from less than $-1.5^{\circ} \mathrm{C}$ to $0^{\circ} \mathrm{C}$ (Fig. 4 ). This water mass extends in the offshore direction to over $200 \mathrm{~km}$ in cold years, with a maximum vertical extent of over $200 \mathrm{~m}$. This cold, relatively fresh (salinities of 32-33) sub-polar shelf water is isolated from the warmer and saltier water $\left(3^{\circ}-4^{\circ} \mathrm{C}\right.$, salinities of 34-35) of the continental slope by a frontal region denoted by a strong horizontal temperature and salinity gradient near the edge of the continental shelf(Narayanan et al., 1991). At $100 \mathrm{~m}$ depth, for example, temperatures normally increase from 0 to $3^{\circ} \mathrm{C}$ at a rate of $0.03^{\circ} \mathrm{C} / \mathrm{km}$.

The panels displayed in Fig. 4 show the summer (midJuly to mid-August) decadal average temperature fields along the Bonavista section (Fig. 1) for the 1960s to the 


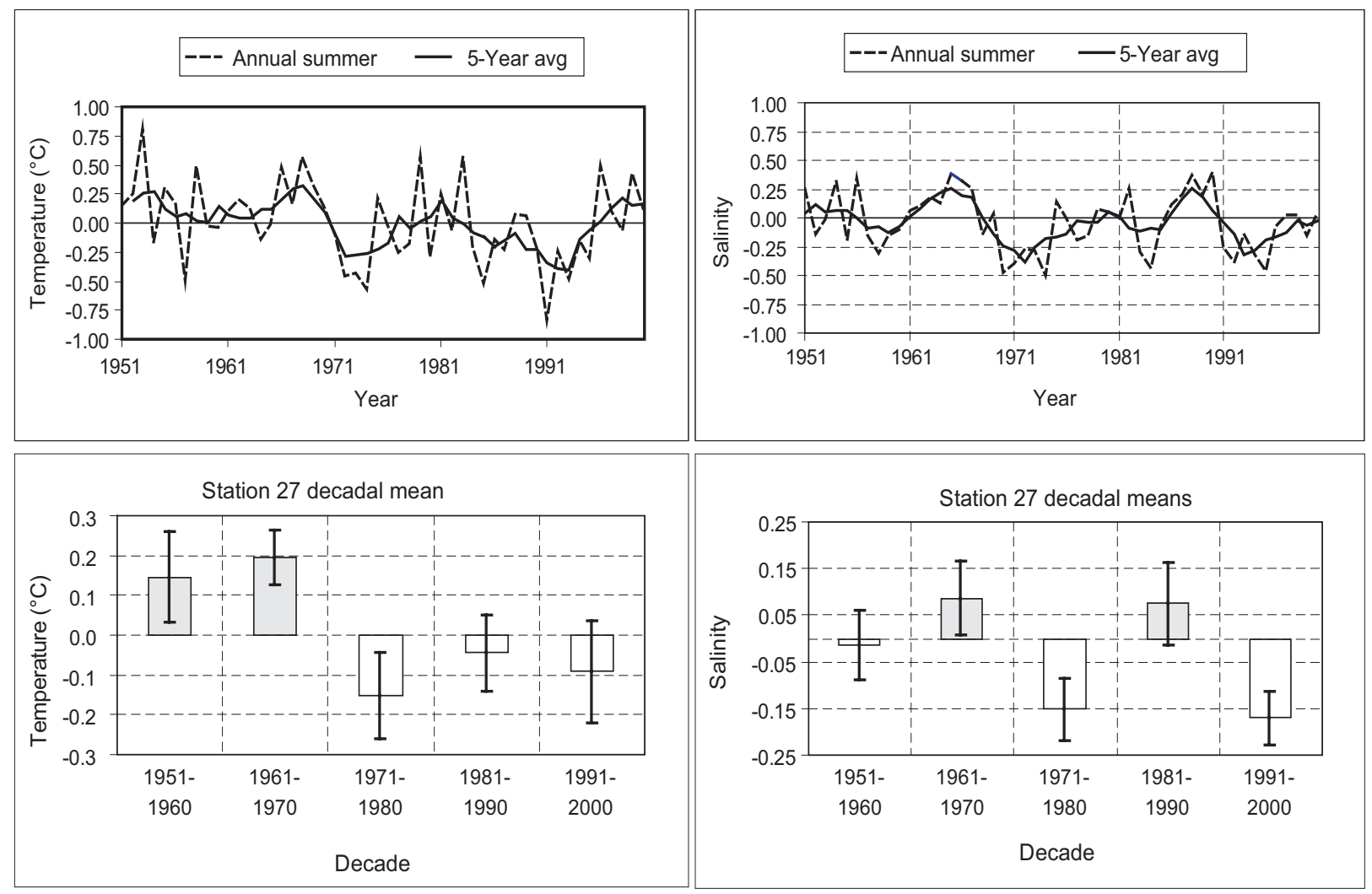

Fig. 3. Station 27 vertically averaged $(0-176 \mathrm{~m})$ annual temperature anomalies and the Station 27 vertically averaged $(0-50 \mathrm{~m})$ summer salinity anomalies (top panels). The heavy lines are the 5-year running means. The bottom panels are their decadal means \pm 1 standard error.

1990s. It is clear that the extent of $<0^{\circ} \mathrm{C}$ water during the decade of the 1960 s was at a minimum, with near-bottom temperatures $>2{ }^{\circ} \mathrm{C}$ penetrating to within $40 \mathrm{~km}$ from the coast. In contrast, during the decade of the 1980s the extent of the cold water mass was at a maximum, but by the 1990s its vertical extent had decreased slightly. Note also the large area of water with temperatures $<-1{ }^{\circ} \mathrm{C}$ during the past two decades compared with earlier periods. The seasonally heated near-surface layer during the 1990s, however, appeared to be colder by up to $2^{\circ} \mathrm{C}$, compared with the other decades. Near-bottom temperatures in water depths below $250 \mathrm{~m}$ averaged over the decade of the $1990 \mathrm{~s}$ were comparable to the $1960 \mathrm{~s}$, generally $1^{\circ}-3^{\circ} \mathrm{C}$.

One of the most robust indices of environmental conditions and indeed of climate conditions on eastern Canadian shelves in general, which is derived from these sections is the extent or area of the cold intermediate layer (CIL), defined as water with temperatures $<0^{\circ} \mathrm{C}$, overlying the continental shelf. The physical mechanisms leading to the formation of this water mass have been described many times (Petrie et al., 1988; Colbourne et al., 1994; Drinkwater, 1996). Essentially, the combined effects of seasonal air-sea heat fluxes, intense winter convection and summer shelf stratification are the primary mechanisms. The CIL during the summer months remains relatively isolated between the seasonally heated upper layer and the deeper shelf-slope water but undergoes a gradual decay during autumn due to intense vertical mixing. Variability in these forcing mechanisms together with variations in advection rates contribute to the observed variability in the thermohaline properties of the shelf water. The CIL index therefore, is a measure of the strength of the seasonal forcing and hence is correlated with the large-scale winter atmospheric circulation (NAO), air temperatures and winter and spring sea-ice cover on the Newfoundland Shelf. For example, the long-term trends in the summer Bonavista CIL area are moderately associated with the winter NAO index $\left(r^{2}=0.4\right)$.

In the late 1950s, the amount of cold water on the Newfoundland Shelf began declining and by the mid1960s the volume of CIL water on the Newfoundland Shelf reached the lowest value observed in the time series (Fig. 5). During the early years of the decades of the 1970s to 1990 s however, the CIL area reached very high values, 

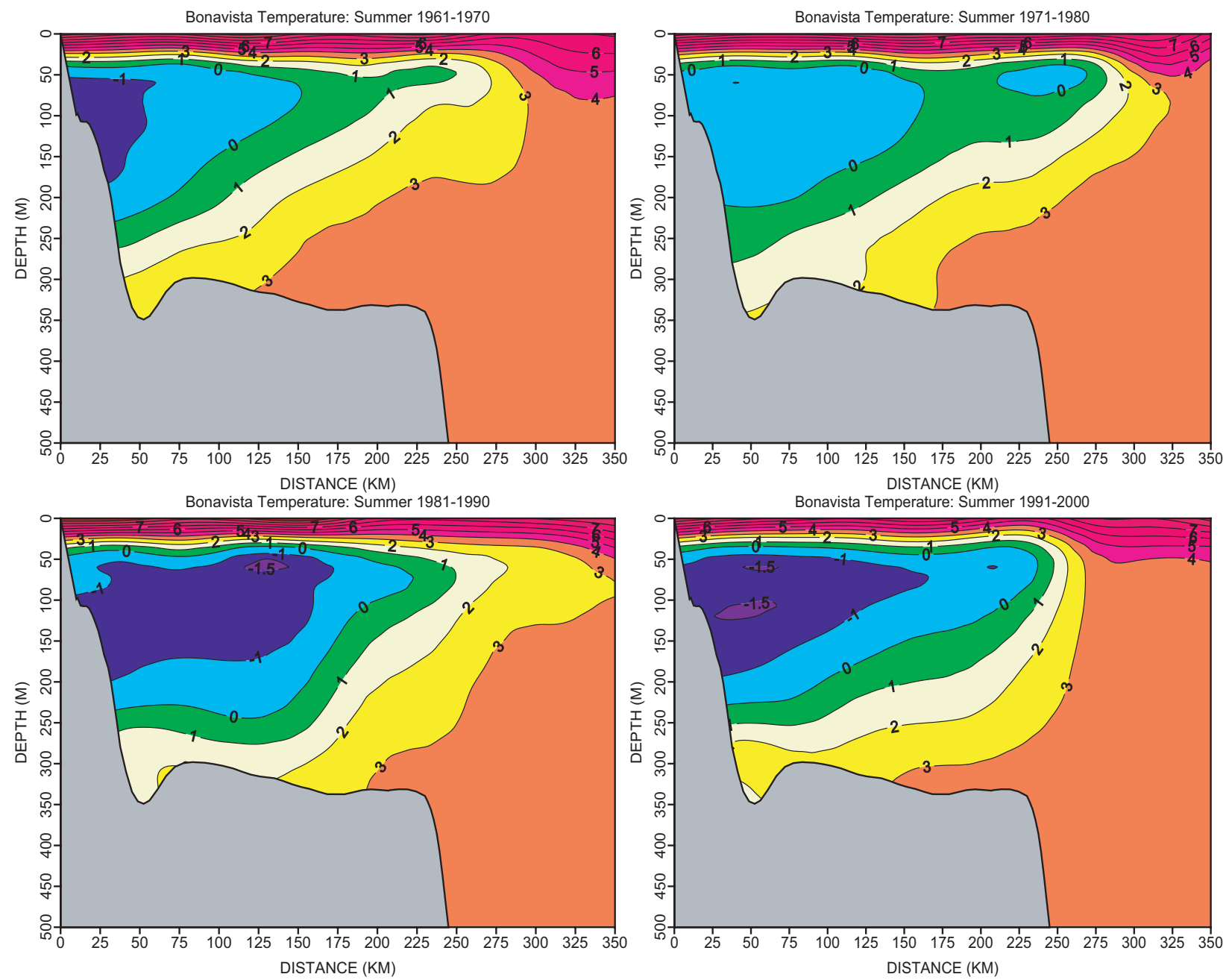

Fig. 4. The averaged vertical temperature field observed along the standard Bonavista section (Fig. 1) for the decades of the 1960s, 1970s, 1980s and 1990s.

coincident with the negative temperature anomalies observed at Station 27 (Fig. 2). The maximum area of CIL water measured on the Newfoundland Shelf along the Bonavista section was in 1984. In general, the CIL time series for all three sections from the Grand Bank (Flemish Cap section) to Hamilton Bank (Seal Island section) on the southern Labrador Shelf show annual differences but are highly correlated. The persistent positive anomaly of the CIL area along the Flemish Cap section up to at least 1997 is most likely related to the topography of the Grand Bank. The lack of significant indentations in the topography and the relatively shallow $(<200 \mathrm{~m})$ water of the Grand Bank restrict warmer slope-water from penetrating shoreward, hence variations in the CIL area on the Grand Bank are determined mainly by atmosphere-ocean heat flux and vertical mixing. Examinations of historical data along sections further north (e.g., Bonavista section) indicate that the CIL area is strongly influenced by intrusions of relatively deep $(>300 \mathrm{~m})$ and warm $\left(>2^{\circ} \mathrm{C}\right)$ slope water. The decadal mean CIL areas for all three sections (Fig. 5) show below normal values in the 1960s and a near normal decadal mean during the 1980s, except for the Grand Bank along the Flemish Cap section. The decade of the 1980s had the highest observed values of $<0^{\circ} \mathrm{C}$ water and during the 1990s, except for the Grand Bank, the amount of $<0^{\circ} \mathrm{C}$ water was about average. Except for the 1950s, all decades exhibited similar variability and at the one standard error level, the decades of the 1950s, 1970s and 1990s were not significantly different (Fig. 5).

Grand Bank Bottom Temperatures. The average near-bottom temperature contours for the decades of the 1960s, 1970s, 1980s and the 1990s based on the bottom trawl survey temperature data are displayed in Fig. 6. In general, bottom temperatures on the Grand Bank are strongly influenced by the local bathymetry, 


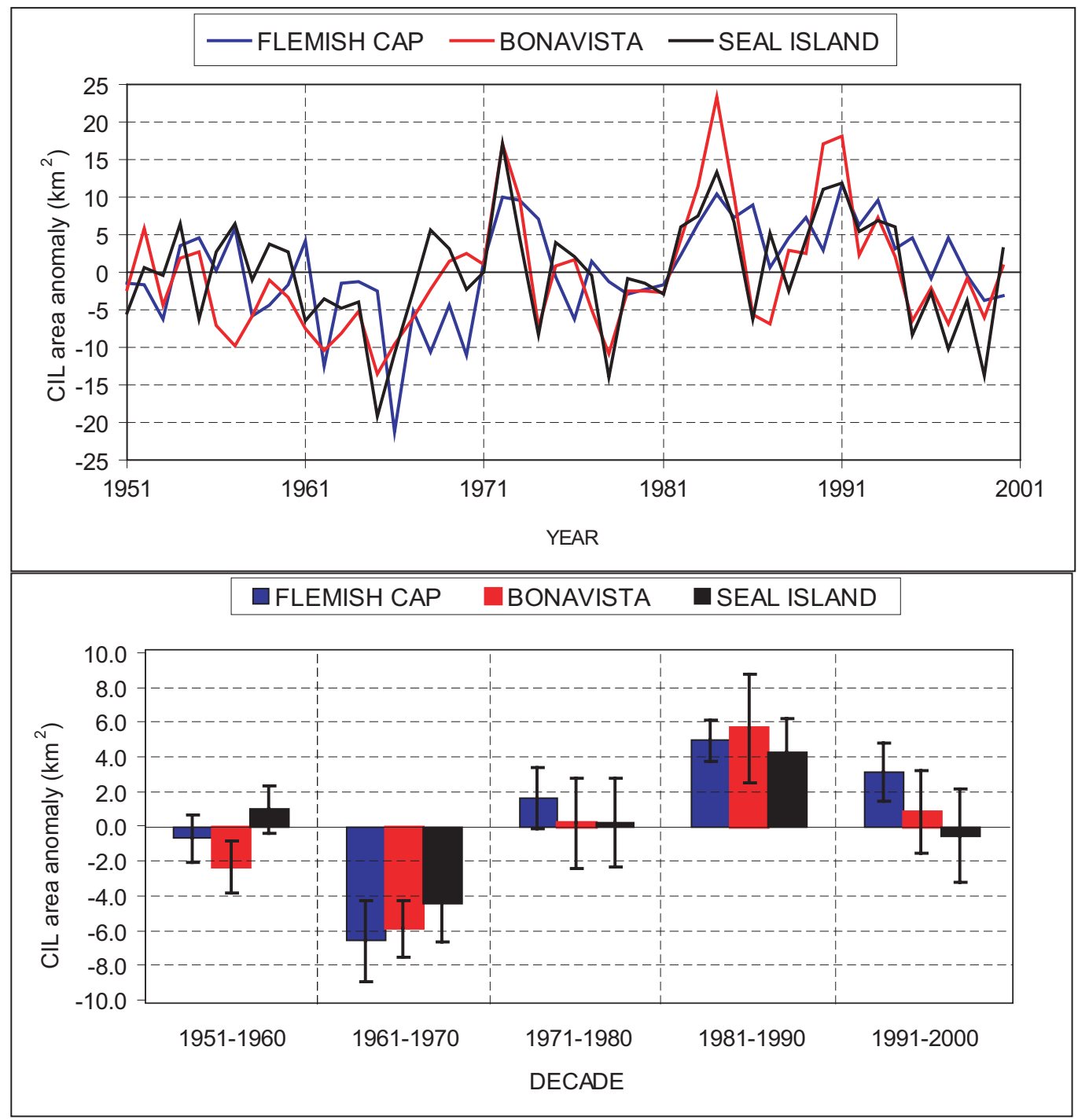

Fig. 5. Annual summer CIL cross-sectional area (top panel) anomalies along the Flemish Cap, Bonavista and Seal Island standard sections and their decadal means \pm 1 standard error (bottom panel).

with strong thermal gradients over the slope regions where temperatures typically increase from $1^{\circ}-3^{\circ} \mathrm{C}$ over distances of a few kilometres. The cold $<0^{\circ} \mathrm{C}$ water, which is mainly restricted to NAFO Division $3 \mathrm{~L}$, is associated with the CIL waters described earlier. The warmer bottom water $\left(1^{\circ}-3^{\circ} \mathrm{C}\right)$ in the southern areas of Division $3 \mathrm{NO}$ is associated with shelf-slope intrusions from the south and from solar heat input on the shallow south-east shoal of the Grand Bank, where water depths are generally $<75$ $\mathrm{m}$. During the decade of the $1960 \mathrm{~s}$ the amount of $<0^{\circ} \mathrm{C}$ water was at a minimum in NAFO Division $3 \mathrm{~L}$ and almost all of the bottom habitat in Divisions 3NO had bottom temperatures ranging from $1^{\circ}-3^{\circ} \mathrm{C}$. By the $1970 \mathrm{~s}$ however, the areal extent of $<0^{\circ} \mathrm{C}$ water had expanded significantly and by the 1980 s these cooler waters covered almost the entire northern Grand Bank. Relatively warm water persisted in the southernmost areas, although it covered slightly less area than during the 1960s. Bottom temperature conditions averaged over the decade of the 1990 s were very similar to the 1980 s, much colder than both the 1960s and 1970s.

Spatially-averaged bottom temperatures for NAFO Divisions 3LNO during the decades of the 1980s and 1990s are displayed in Fig. 7. These estimates show large interannual variations, particularly during the early-1980s, and a general decline that started in 1984 and continued until the end of the decade, when the temperatures reached the minimum of the 20 -year record. The low temperatures on the Grand Bank $\left(<1^{\circ} \mathrm{C}\right)$ continued until at least 1995, after 

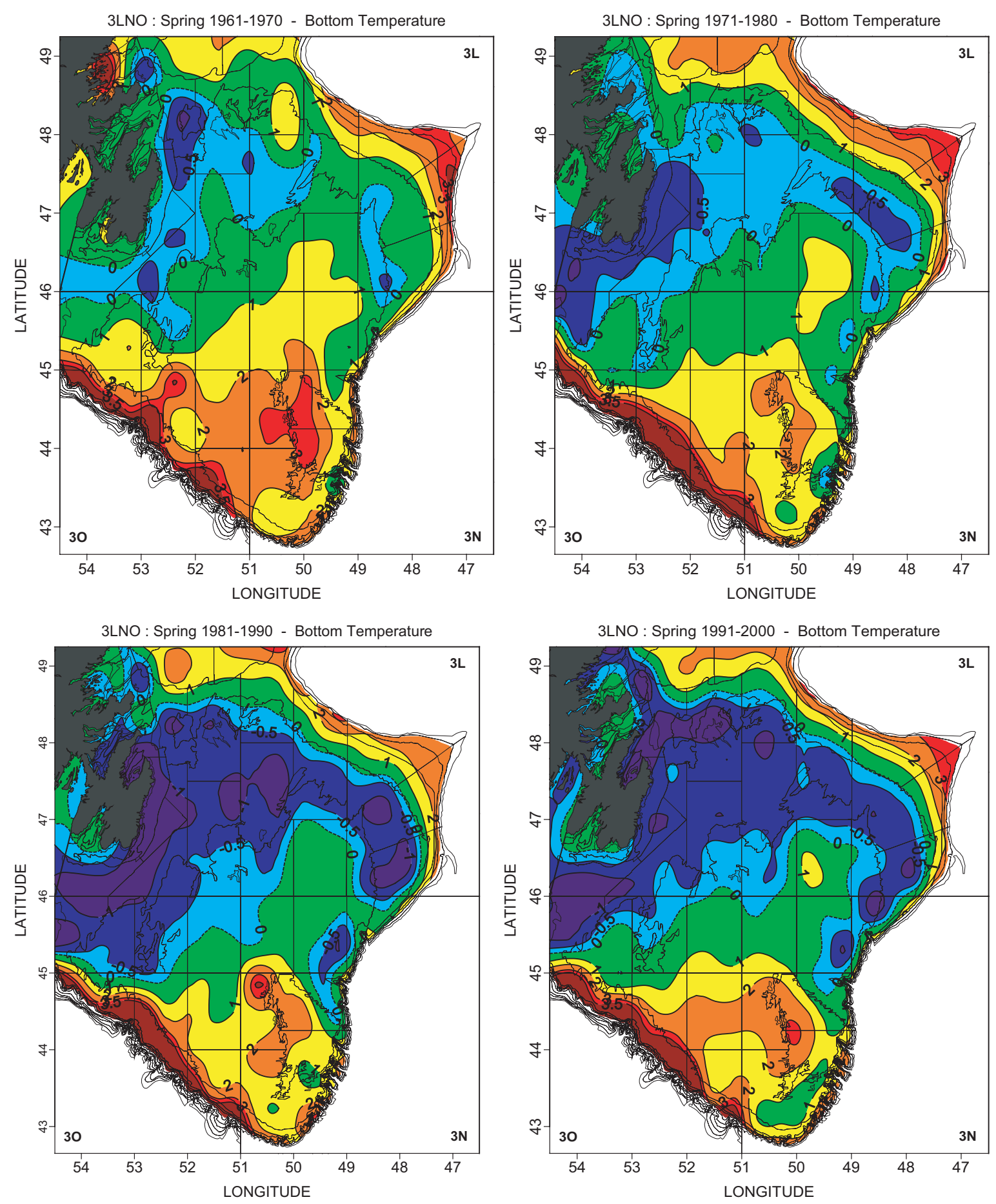

Fig. 6. Contours of spring bottom temperature (in ${ }^{\circ} \mathrm{C}$ ) based on all available data collected during the decades of the 1960s, 1970s, 1980s and the 1990s for NAFO Div. 3LNO. The boundaries of fishing strata are also indicated.

which a slight recovery commenced. Towards the end of the decade of the 1990s bottom temperatures increased over the lows of the early 1990s, with the average bottom temperature during the spring of 1999 and 2000 reaching
$2{ }^{\circ} \mathrm{C}$. The highest temperature in the 25 -year record occurred in 1983, when the average temperature was $3.2^{\circ} \mathrm{C}$ and the lowest temperature of $0.25^{\circ} \mathrm{C}$ occurred in 1990. In general, the decade of the 1980s was one of 
declining bottom temperatures, in contrast to the generally increasing trend during most of the 1990s (Fig. 7).

Changes in the thermal habitat of demersal marine organisms in a particular region can be estimated by computing the percent area of the bottom, for example, covered by water in selected temperature ranges. During the 1980s the percent area of the Grand Bank with $<0^{\circ} \mathrm{C}$ water increased from $20 \%$ in 1981 to near $50 \%$ during the latter half of the decade (Fig. 7). At the beginning of the decade of the 1990s the area of $<0^{\circ} \mathrm{C}$ water was at a record maximum, well over $50 \%$, which remained relatively constant between 40-50\% until 1995. Beginning in 1995 the percent area of $<0^{\circ} \mathrm{C}$ water began to decline reaching a record low of near $10 \%$ by 1999 . During this period there was a corresponding increase in the area covered by water $\geq 1^{\circ} \mathrm{C}$ reaching $50-60 \%$ by the spring of 1998 and 1999 , the largest area of relatively warm water on the Grand Bank since the late 1970s (Colbourne, MS 2001).

The Decade of the 1990s. During the first half of the 1990s the NAO index was well above its long-term mean, reaching the third highest value of this century by 1995. During the winter of 1996 it underwent a sharp

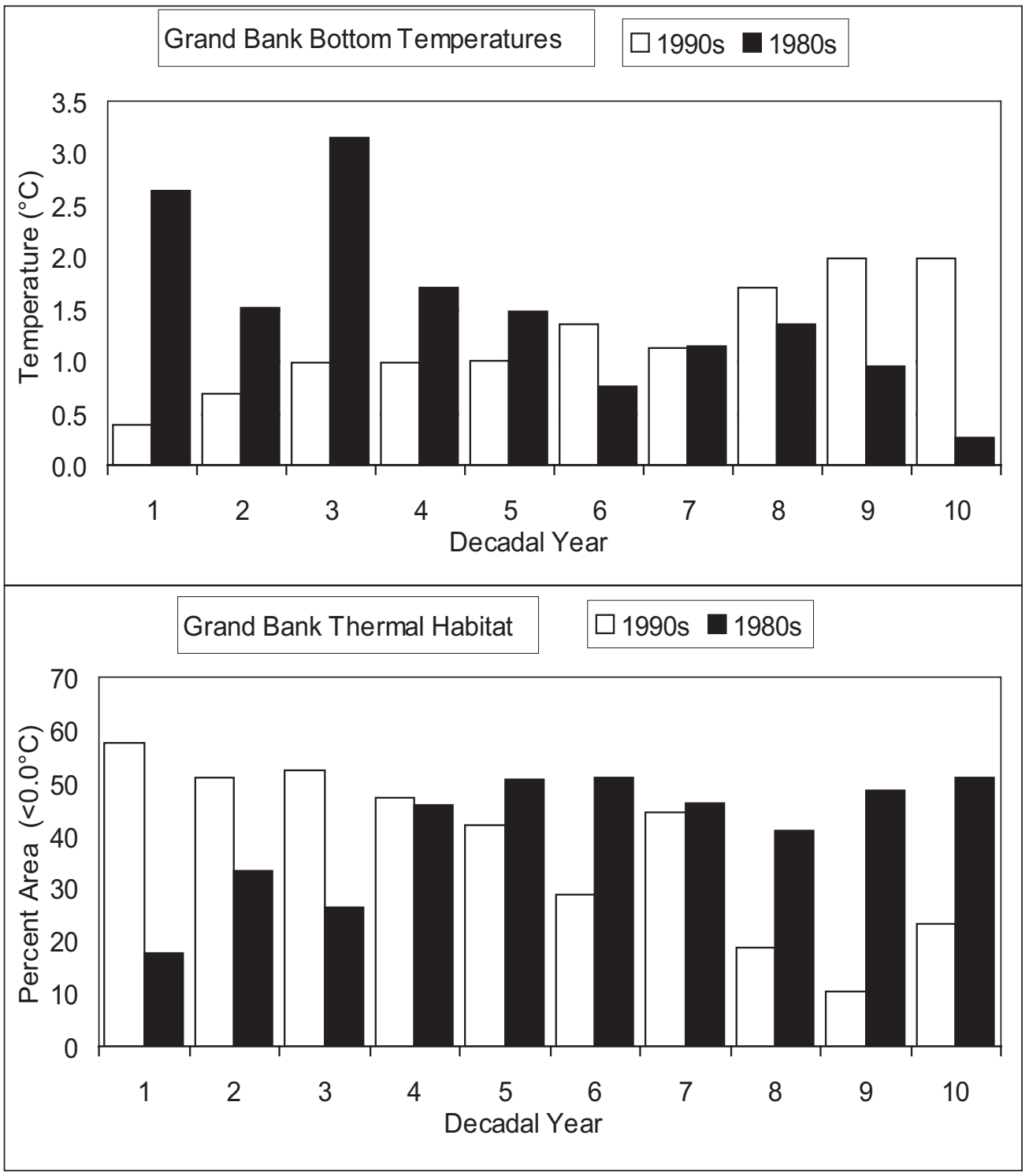

Fig. 7. The annual spatially averaged spring bottom temperature in NAFO Div. 3LNO for the decades of the 1980s and 1990s (top panel) and the area of the bottom covered with water at temperatures $<0^{\circ} \mathrm{C}$ (bottom panel). 
reversal, decreasing to the lowest value since 1979 and one of the 10 most negative values this century (ICES, 2001). In response to these changes in the NAO, climate conditions in the Northwest Atlantic and the ocean environment on the eastern Canadian Continental Shelf during the decade of the 1990s experienced some of the most extreme variations since measurements began during the mid-1940s. Annual air temperatures increased from near record lows during the early-1990s to above normal values in 1996, and to record highs in 1999, setting a 126-year record over Newfoundland and a 65-year record over Labrador (Drinkwater et al., MS 2000). Sea ice extent on the Newfoundland Shelf decreased rapidly from the heavy ice years of 1990-94 to the lightest iceyear since 1969 by 1996 . Below normal sea ice extent and duration continued to the end of the decade (Drinkwater et al., 2001).

Changes in the heat content of the water column as a result of the extreme variations in meteorological and sea ice conditions are evident by comparing the annual temperature fields at Station 27 and along the Bonavista section during the most extreme years of the 1990s (Fig. 8 and 9). At Station 27, for example, the annual surface warming (comparing the $1^{\circ} \mathrm{C}$ contour) was delayed by 1.5 months during 1991 compared with 1999. In 1991, the peak late-summer surface temperatures were up to $4^{\circ} \mathrm{C}$ colder and the sub-surface values ranged from $1^{\circ}-2^{\circ} \mathrm{C}$ colder compared with 1999 (Fig. 8). Temperatures in the near-surface waters $(0-25 \mathrm{~m})$ along the Bonavista section during 1991 ranged from $2^{\circ}-5^{\circ} \mathrm{C}$ compared to $5^{\circ}-10^{\circ} \mathrm{C}$ during 1999 . Temperatures below $200 \mathrm{~m}$ ranged from $-1.5^{\circ}-2^{\circ} \mathrm{C}$ on the inner shelf in 1991 within $100 \mathrm{~km}$ from the coast compared to $0^{\circ}-3^{\circ} \mathrm{C}$ during 1999 . Bottom temperatures on the outer shelf areas were very similar $\left(>3^{\circ} \mathrm{C}\right.$ ) during both 1991 and 1999 (Fig. 9). In addition, there were significant changes in the area or volume of CIL waters on the Newfoundland Shelf within the 1990s (Fig. 5, 9, and 10). For example, along the Seal Island section (Fig. 1) the area of the CIL ranged from the third highest in the record in 1991 to the third lowest in 1999 (Fig. 5 and 10). The 1999 CIL area on the southern Labrador Shelf along the Seal Island section was the lowest measured since 1978, a 22-year record. Off eastern Newfoundland, the 1991 Bonavista section CIL area was the second highest on record and values during the latter years of the decade were among the lowest recorded.

The thermal habitat of many demersal fish species on the eastern Canadian Shelf, particularly on the Grand Bank of Newfoundland, also shifted from one extreme to the other during the past decade. Off eastern Newfoundland and on the southern Labrador Shelf bottom temperatures decreased to $<0^{\circ} \mathrm{C}$ by the early 1990s, reaching a minimum of $-1^{\circ} \mathrm{C}$ by 1993 on Hamilton Bank and to $-0.5^{\circ} \mathrm{C}$ on the southern Newfoundland Shelf at Station 27 (Fig. 10). During 1994 bottom temperatures began to increase reaching positive values by 1996, a trend that continued to the end of the decade (Fig. 10). During the cold years of the early 1990s most of the Grand Bank (except the deeper slope regions) and the southern most areas were covered by $<0^{\circ} \mathrm{C}$ water with a large area of the northern half of the Grand Bank covered with $<-1{ }^{\circ} \mathrm{C}$ water (Fig. 11). During these years temperatures for the most part were below normal over the entire region, with anomalies reaching at least $0.5^{\circ} \mathrm{C}$ below normal, but as low as $2^{\circ} \mathrm{C}$ below normal in some regions (Colbourne, 2001). By the mid-1990s the area of $<0^{\circ} \mathrm{C}$ water began to retract and by 1999 was restricted to a small area near the south-east coast of Newfoundland. Bottom water temperatures $<-1{ }^{\circ} \mathrm{C}$ had completely disappeared by the end of the decade of the 1990s. In the southern regions of the Grand Bank during the spring of 1999, for example, temperatures reached over $3.5^{\circ} \mathrm{C}$ and warmed to over $8^{\circ} \mathrm{C}$ during the fall of that year. As a result, above normal conditions persisted over the entire Grand Bank with temperatures up to $1^{\circ} \mathrm{C}$ above average in northern areas and up to $4^{\circ} \mathrm{C}$ above normal on the southern Grand Bank during the fall (Colbourne, MS 2001).

\section{Discussion and Summary}

The latter half of the $20^{\text {th }}$ century has been a period of considerable variability in the physical environment in NAFO waters of the Northwest Atlantic. During the decades of the 1950s and 1960s the ocean environment was dominated by a general warming phase that reached its maximum by the mid-to-late 1960s. Beginning in the early-1970s however, climate conditions in the Northwest Atlantic experienced near-decadal oscillations, with a general downward trend in ocean temperatures. The decadal mean temperatures show that the 1950s and particularly the 1960 s were the warmest in the 50-plus year record and the decade of the 1990s was the third consecutive decade with below normal temperatures on the Newfoundland Shelf. The magnitude of the negative salinity anomaly on the inner Newfoundland Shelf during the decade of the 1990s was comparable to that experienced during the 'Great Salinity Anomaly' of the early-1970s.

In summary, during the last several decades, water properties (temperature/salinity) on the Newfoundland Shelf showed extreme variability, often exhibiting different phase responses during different time periods both within and between decades. During the 1990s, for example, the Northwest Atlantic experienced some of the most extreme variations in ocean conditions since measurements began in the mid-1940s. Off eastern 


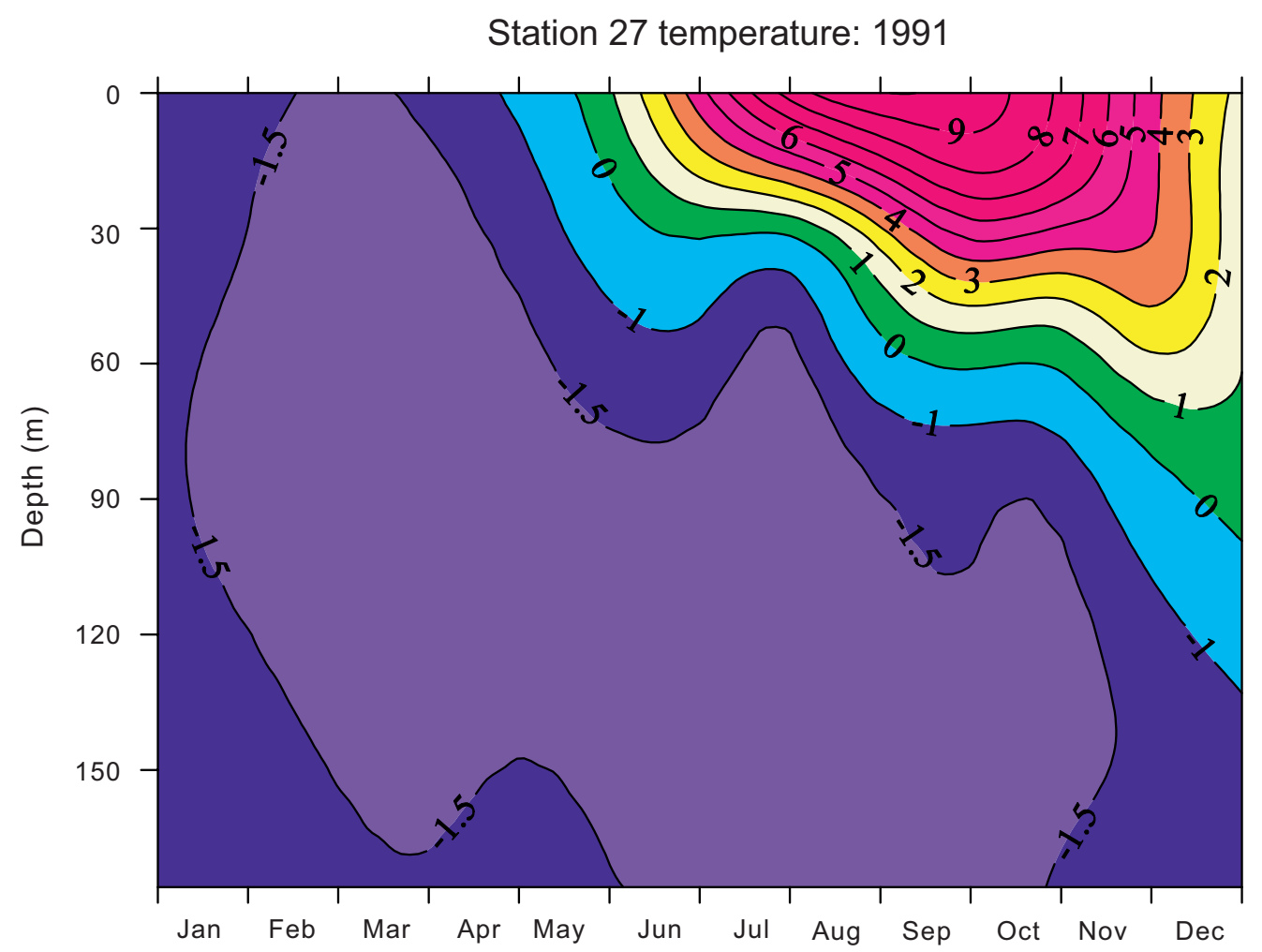

Station 27 temperature: 1999

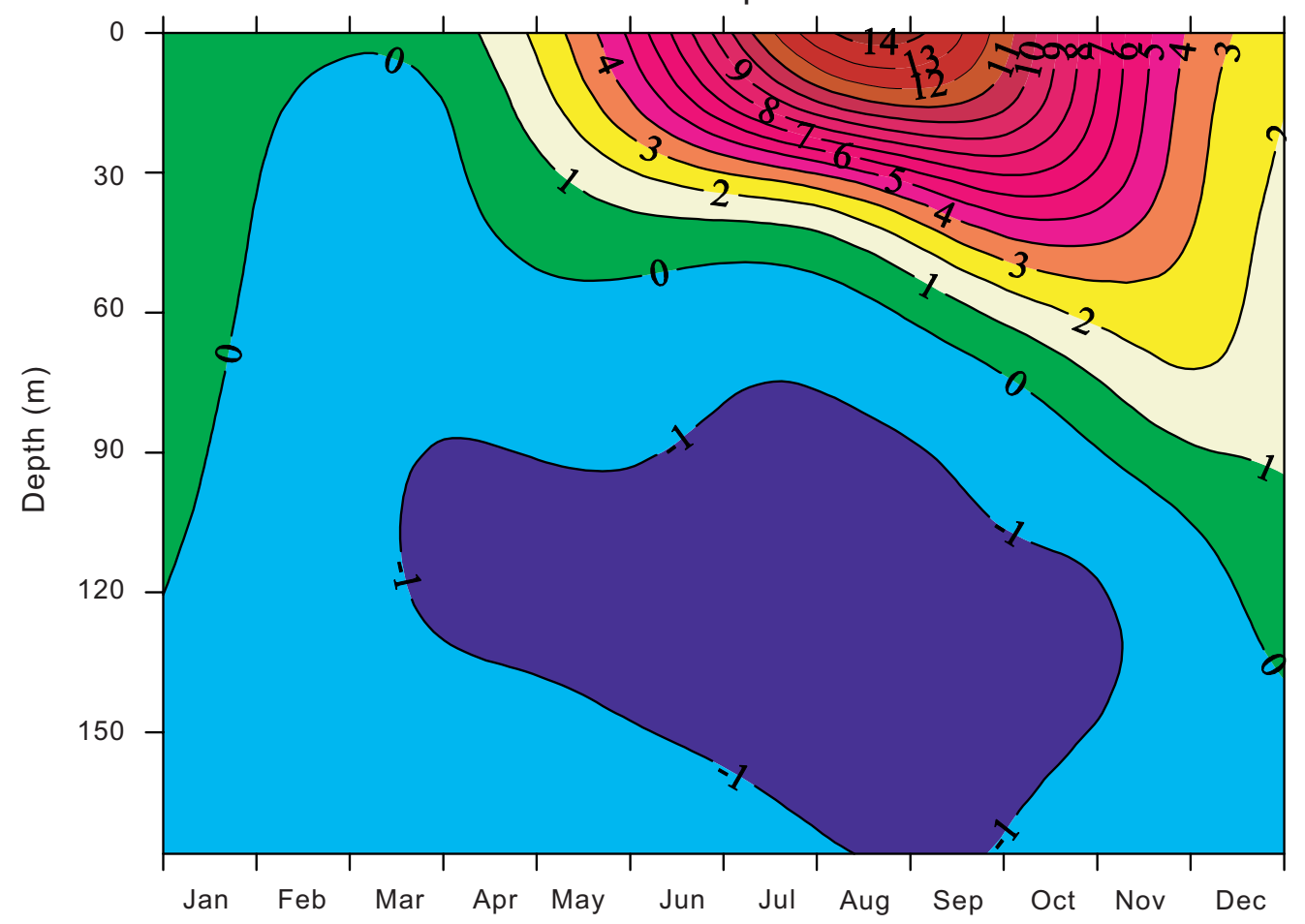

Fig. 8. Monthly temperatures as a function of depth observed at Station 27 (Fig. 1) for 1991 and 1999. 

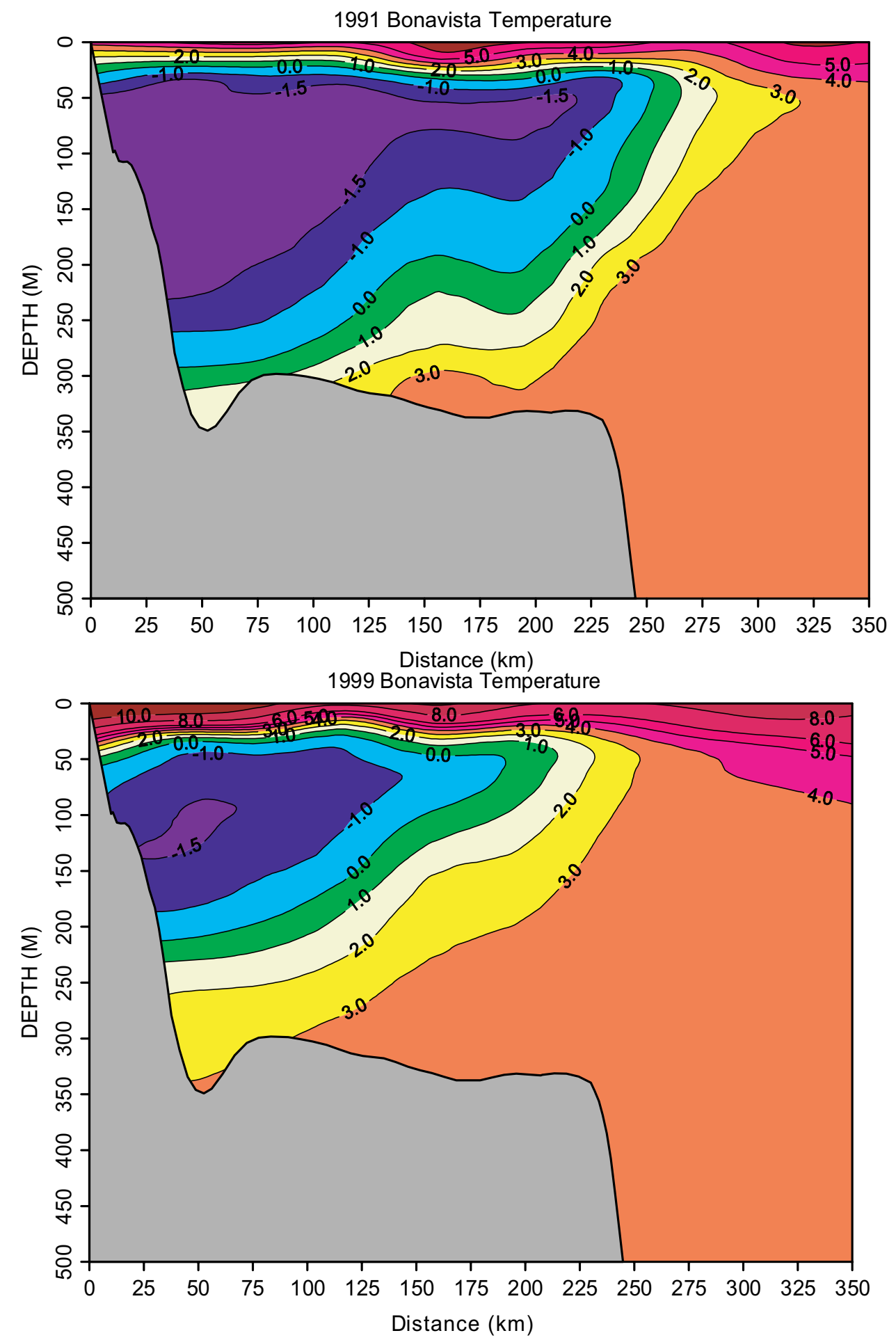

Fig. 9. The vertical temperature structure observed along the standard Bonavista section (Fig. 1) for the summers of 1991 and 1999.

Newfoundland and on the southern Labrador Shelf bottom temperatures ranged from near record lows during 1991 to some of the highest values on record by the late 1990s. The extreme variability in water properties is due to differences in the phase and amplitude in the seasonal cycles of solar heat input, air-sea sensible and latent 


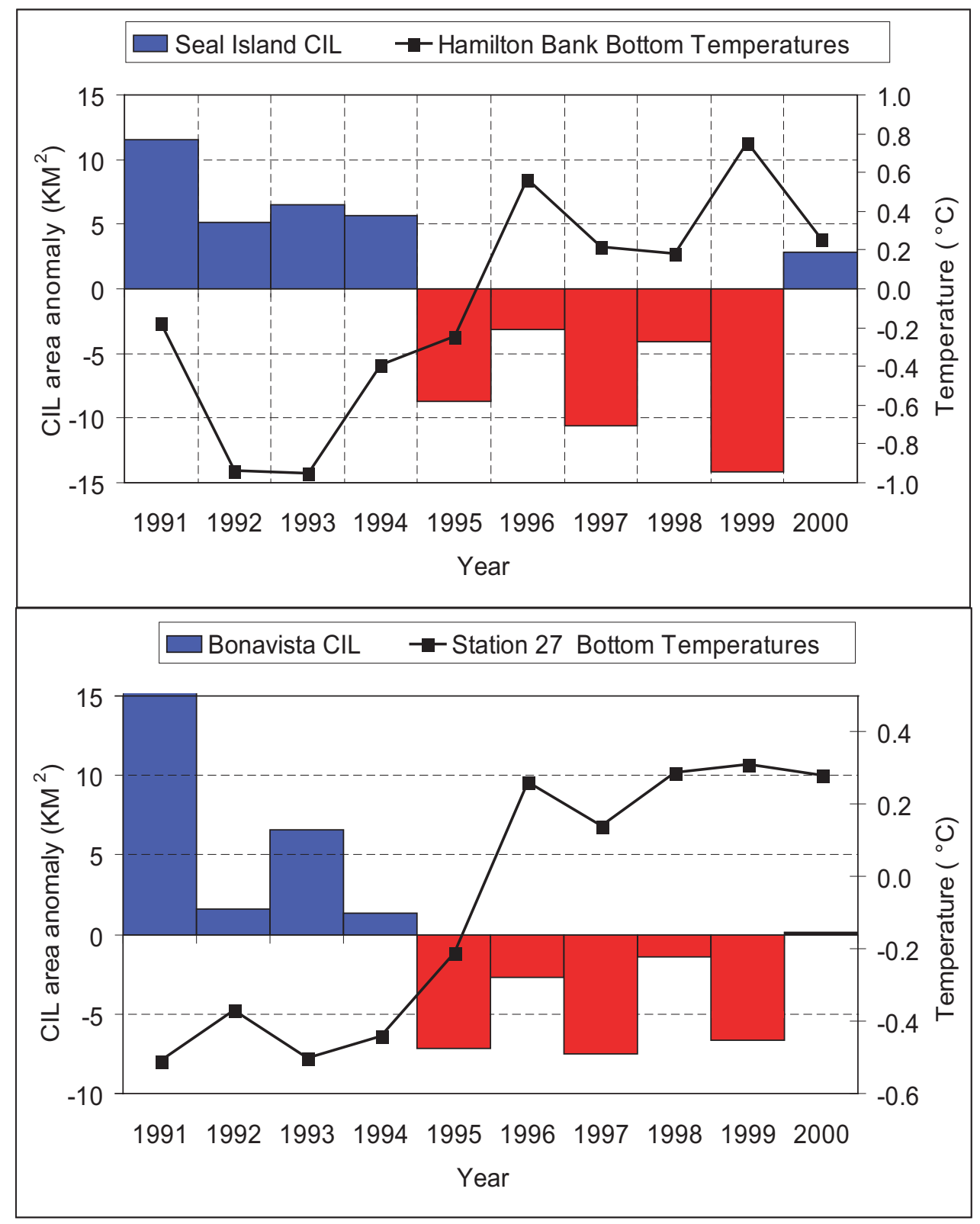

Fig. 10. The CIL area anomalies for the Seal Island standard section and the Hamilton Bank mean fall bottom temperature for the decade of the 1990s (top panel) and the CIL anomalies for the Bonavista section together with the Station 27 bottom temperature for the 1990s (bottom panel). The CIL anomalies, which are coloured blue, indicate above normal area of cold water and red indicate years with below normal CIL area or warm conditions.

heat fluxes, sea ice dynamics and variations in advection rates of the Labrador Current. The sea-surface pressure field, from which the NAO index is derived and which is one of the largest scale forcing mechanisms affecting the ocean climate in the North Atlantic, also experienced extreme spatial variability during the end of the 1990s. This resulted in a breakdown in the expected ocean response in the Northwest Atlantic to changes in the NAO patterns, particularly during 1999 and 2000 (ICES, 2001; Colbourne and Anderson, 2003).

One common feature in the ocean climate during the past three decades however, is the extremely cold-water temperature during the early part of each decade and the generally warmer conditions towards the second half of each decade. This was especially true during the decade 

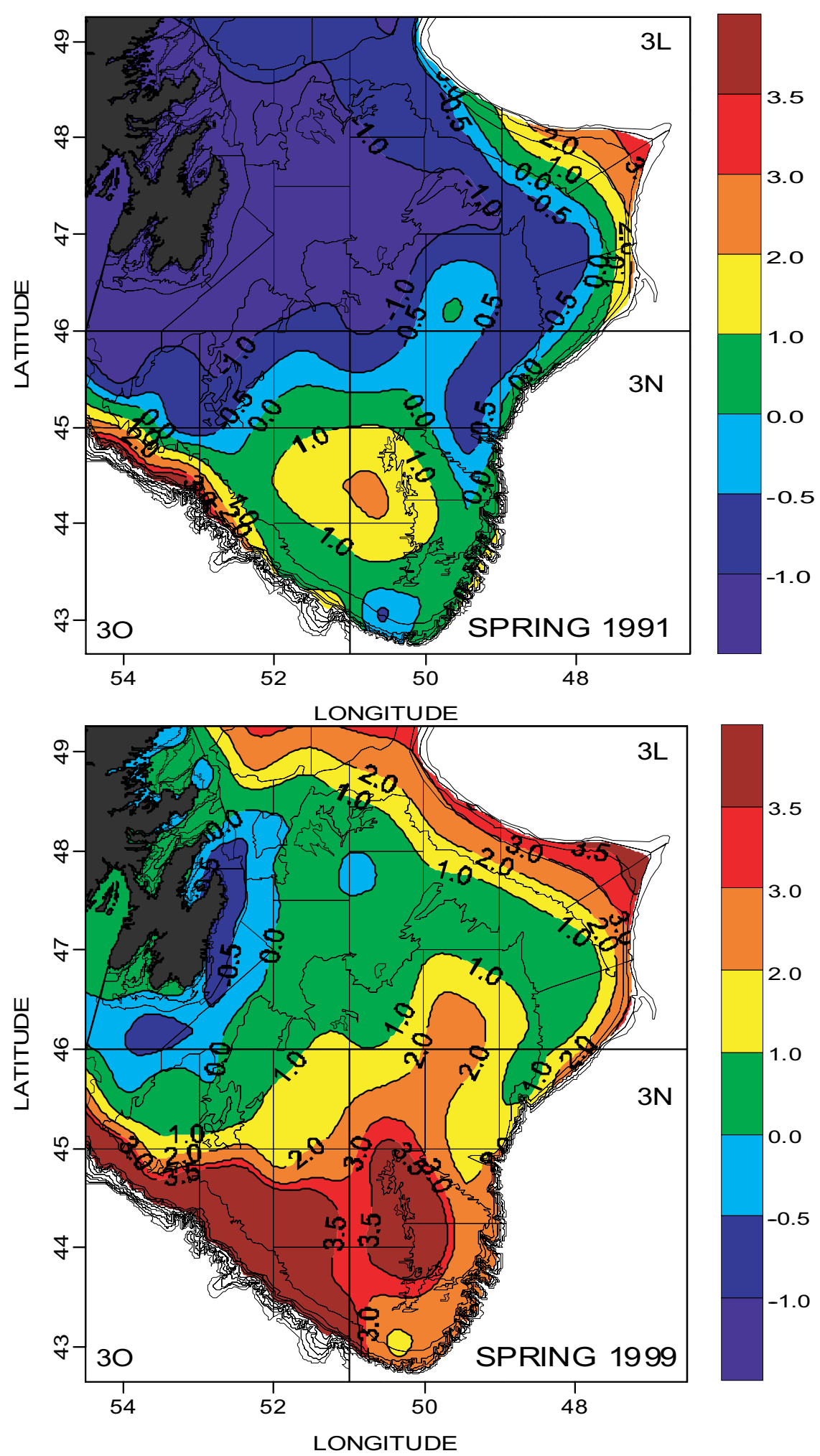

Fig. 11. Contours of spring bottom temperature (in ${ }^{\circ} \mathrm{C}$ ) based on data collected during the multi-species surveys in NAFO Divs. 3LNO for 1991 and 1999. The boundaries of various fishing strata are also indicated. 
of the 1990s. For example, the three highest CIL areas measured on the Newfoundland Shelf occurred during 1972, 1984 and 1991 along all three sections shown in Fig. 1. On the other hand, there was a significant difference in the water salinity on the inner Newfoundland Shelf between the decade of the 1990s and the previous two decades. Salinities during the 1990s at most depths remained below normal throughout the decade, in contrast to the previous two decades when salinities increased more or less in phase with the increasing temperature trends during the latter half of each decade. The source of the freshwater observed at Station 27 during the early 1990s was assumed to be due to increased amounts of fresh water from melting sea-ice off Labrador. However, the source of the increased amounts of freshwater during the latter part of the 1990s needs to be investigated. The record high air temperatures experienced in northern regions during the late 1990s may have led to increased amounts of sea ice melting at higher latitudes (Parkinson et al., 1999), resulting in larger amounts of freshwater flowing south throughout most of the year.

The NAFO waters of the Northwest Atlantic and particularly the Newfoundland and Labrador shelf regions are a habitat to many marine species of demersal fish and crustacean populations. Many of these species are at the northern limit of their distributions within a very limited thermal habitat. It is not unreasonable therefore, to expect changes in ocean temperature at this northern limit to be an important factor influencing marine production. Indeed, several studies have suggested that variations in the physical ocean environment influences growth, recruitment and distribution of many marine organisms in Newfoundland waters (deYoung and Rose, 1993; Myers et al., 1993; Rose et al., 1994; Rose et al., 1995; Taggart et al., 1994; Narayanan et al., 1994; Colbourne et al., 1997b; Carscadden et al., 2001; Parsons and Lear, 2001; Colbourne and Anderson, 2003). The interactions between the marine environment and production, however, are complicated, usually non-linear, and operate through complex mechanisms throughout several trophic levels of the ecosystem over a broad range of time and space scales. These interactions are further complicated by variations in fishing mortality. Therefore, the significance of correlations between individual environmental indices and measures of marine production is most often marginal at best and often breaks down as different factors predominate.

The analysis presented here suggests that the ocean climate on the Newfoundland Shelf has changed on decadal time scales with the last three decades all showing significantly lower average temperatures compared with the 1950s and 1960s. Coincident with these climate variations many commercial fish species have shown dramatic changes in distribution and abundance on similar time scales. Recruitment in Newfoundland cod stocks, for example, declined almost steadily since the 1960s, reaching historical low values by the early-1990s (Stansbury et al., MS 1999; Lilly et al., MS 1999). The correlations shown in Fig. 12 between the air temperatures, the area of CIL water, and Atlantic cod (Gadus morhua) recruitment with the NAO are consistent with the scenario outlined by Mann and Drinkwater (1994) on the physical mechanisms that lead to ecosystem productivity. We find strong correlations between the NAO and air temperatures and the amount of CIL water on the Newfoundland Shelf. Furthermore, high recruitment in the southern Grand Bank cod (Div. 3NO) is associated with negative $\mathrm{NAO}$ anomalies and generally warmer ocean climate conditions.

Within the decade of the 1990s water properties in the Newfoundland region have experienced extreme variations from record low ocean temperatures during the first half of the decade to a record high by the late 1990s. This shift in the thermal habitat from the Arcticlike conditions of the early-1990s to the more temperate conditions of the late-1990s most likely contributed to the observed changes in the pelagic ecosystem, which showed a significant increase in the nekton biomass during the late1990s (Anderson et al., MS 1999; Dalley et al., MS 2000; Colbourne and Anderson, 2003). In addition, data from the annual multi-species bottom trawl surveys of NAFO Divisions 2J3KLNO (Fig. 1) while showing only a slight increase in the biomass of cod from 1995 to 1997 showed a $70 \%$ increase from 1998 to 1999 during the fall survey (DFO, 2000). Finally, the recently observed expansion in the spatial distribution and increase in abundance of yellowtail flounder (Limanda ferruginea) on the Grand Bank coincided with the improved thermal environment during the latter half of the 1990s (Walsh et al., MS 2000; Colbourne and Bowering, MS 2001). In conclusion, the progressive decline in ocean temperatures, particularly during the past two decades, coincided with the general decline in fish production in Newfoundland waters. However, as noted above, fish production in general depends on many other complex physical and biological processes in addition to changing fishing mortality.

\section{Acknowledgements}

I thank the technical staff of the Northwest Atlantic Fisheries Center for data collection and processing during many oceanographic and fisheries research surveys on the Newfoundland Shelf. Thanks are also extended to the many scientists at the Department of Fisheries and Oceans 


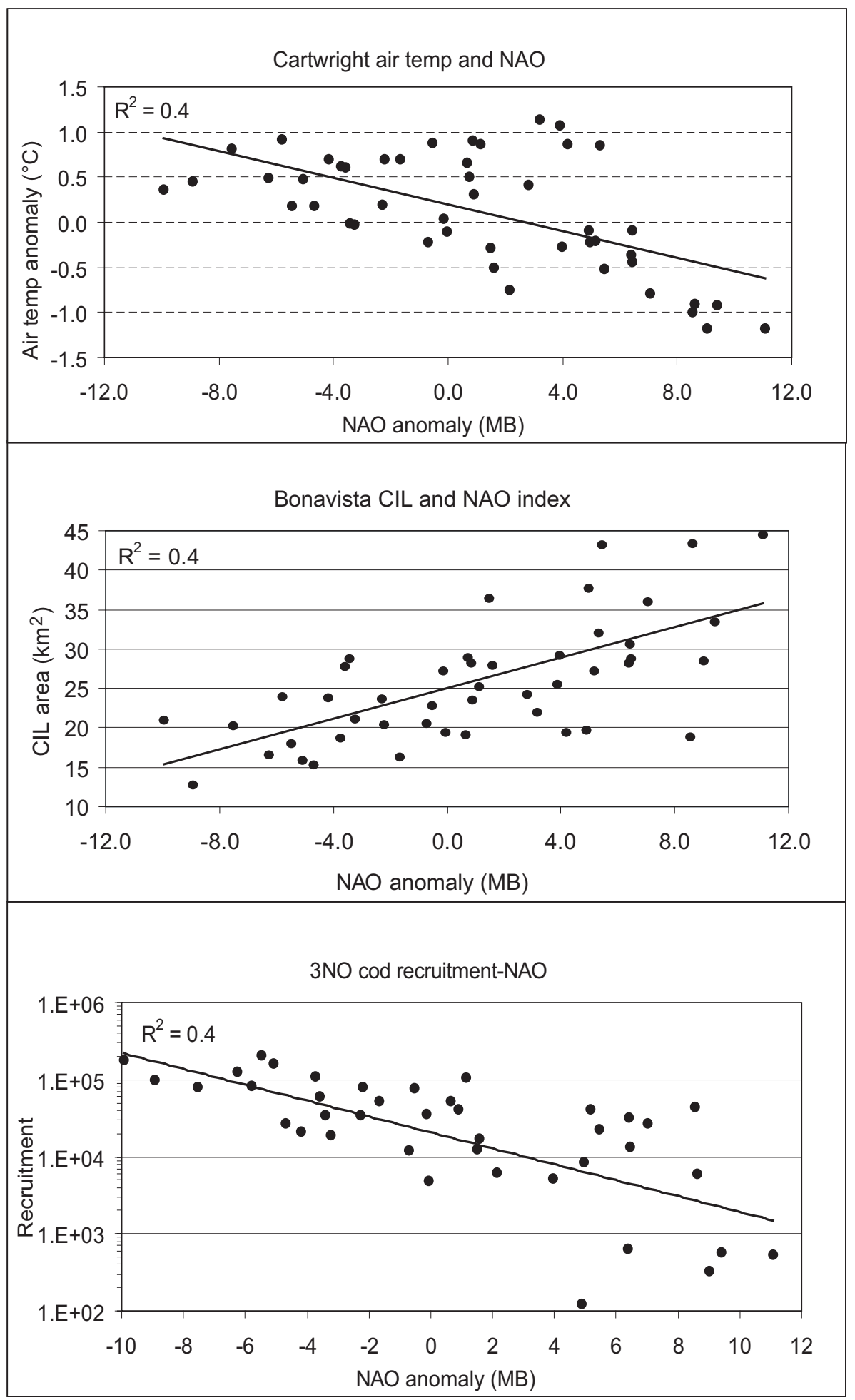

Fig. 12. Correlations between the trends in Labrador air temperatures, Newfoundland Shelf extent of cold $<0^{\circ} \mathrm{C}$ water and recruitment (VPA abundance at age 3) in Grand Bank (3NO) cod with the NAO index anomaly. 
for collecting and providing much of the data contained in this analysis and to the Marine Environmental Data Service (MEDS) in Ottawa for providing most of the historical data. I also thank two anonymous reviewers for many valuable comments and suggestions.

\section{References}

ANDERSON, J.T., E. L. DALLY, and E. B. COLBOURNE. MS 1999. Recent trends in the dominant pelagic fish species and environment in the Northwest Atlantic, NAFO 2J3KLNO. DFO. Atl. Fish. Res. Doc., No. 114, 15 p.

BISHOP, C. A. MS 1994. Revisions and additions to the stratification scheme used during research vessel surveys in NAFO Subareas 2 and 3. NAFO SCR. Doc. No. 43, Serial No. N2413, 23 p.

CARSCADDEN, J. E., K. T. FRANK, and W. C. LEGGETT. 2001. Ecosystem changes and the effects on capelin (Mallotus villosus), a major forage species. Can. J. Fish Aquat. Sci., 58: 73-85.

CHAPMAN, D. C., and R. C. BEARDSLEY. 1989. On the origin of shelf water in the Middle Atlantic Bight. J. Phys. Oceanogr., 19: 384-391.

COLBOURNE, E. B. 2000. Interannual variations in the stratification and transport of the Labrador Current on the Newfoundland Shelf. ICES C.M. Doc., No. 2000/L:02, $12 \mathrm{p}$.

MS 2001. Physical oceanographic conditions on the Newfoundland and Labrador Shelves during 2000. DFO Can. Sci. Advis. Sec. Res. Doc., No. 2001/18b: 58 p.

COLBOURNE, E. B., and J. T. ANDERSON. 2003. Biological response of a changing ocean environment in Newfoundland waters during the latter decades of the 1900s. ICES. Mar. Sci. Symp., 219: 169-181.

COLBOURNE E. B., and W. R. BOWERING. MS 2001. Recent trends in bottom temperatures and distribution and abundance of yellowtail flounder (Limanda ferruginea) in NAFO Divisions $3 \mathrm{LNO}$ during the spring and fall. NAFO SCR Doc., No. 32, Serial No. N4409, 17 p.

COLBOURNE, E. B., and C. FITZPATRICK. 1994. Temperature, salinity and density at Station 27 from 1978 to 1993. Can. Tech. Rep. Hydrogr. Ocean Sci., 159, v +117 p.

COLBOURNE, E., B. DE YOUNG, S. NARAYANAN, and J. HELBIG. 1997a. A comparison of hydrography and circulation on the Newfoundland Shelf during 1990-1993 to the long-term mean. Can. J. Fish. Aquat. Sci., 54 (Supplement 1): 68-80.

COLBOURNE, E., B. DEYOUNG, and G. A. ROSE. 1997b. Environmental analysis of Atlantic cod (Gadus morhua) migration in relation to the seasonal variations on the Northeast Newfoundland Shelf. Can J. Fish. Aquat. Sci., 54 (Supplement 1): 149-157.

COLBOURNE, E. B., S. NARAYANAN, and S. PRINSENBERG. 1994. Climatic change and environmental conditions in the Northwest Atlantic during the period 1970-1993. ICES Mar. Sci. Symp., 198: 311-322.

DALLEY, E. L., J. T. ANDERSEON and D. J. DAVIS. MS 2000. Short term fluctuations in the pelagic ecosystem of the Northwest Atlantic. Can. Stock Assess. Sec. Res. Doc., No. 2000/101, $36 \mathrm{p}$.

DE YOUNG, B., and G. A. ROSE. 1993. On recruitment and distribution of Atlantic cod (Gadus morhua) off Newfoundland. Can J. Fish. Aquat. Sci., 50: 2729-2741.

DFO. 2000. Northern (2J3KL) cod. DFO Sci., Stock Status Rep. A2-01, 13 p.

DICKSON, R.R., J. MEINCKE, S.A. MALMBERG, and A.J. LEE. 1988. The "Great Salinity Anomaly" in the northern North Atlantic 1968-82. Progr. Oceanogr., 20: 103-151.

DOUBLEDAY, W. G. (ed.) 1981. Manual on groundfish surveys in the Northwest Atlantic. NAFO Sci. Coun. Studies, 2: $56 \mathrm{p}$.

DRINKWATER, K. F., E. COLBOURNE, and D. GILBERT. MS 2001. Overview of environmental conditions in the Northwest Atlantic in 2000. NAFO SCR Doc., No. 36, Serial No. N4414, 84 p.

DRINKWATER, K. F., R. PETTIPAS, and L. PETRIE. MS 2000. Overview of meteorological and sea ice conditions off eastern Canada during 1999. Can. Stock Assess. Sec. Res. Doc., No. 2000/59, 28 p.

DRINKWATER, K. F. 1996. Atmospheric and oceanic variability in the Northwest Atlantic during the 1980s and early 1990s. J. Northw. Atl. Fish. Sci., 18: 77-97.

GREENBERG, D. A., and B. D. PETRIE. 1988. The mean barotropic circulation on the Newfoundland shelf and slope. J. Geophys. Res., 93: 15 541-15 550.

HACHEY, H. B., F. HERMANN, and W. B. BAILEY. 1954. The waters of the ICNAF Convention Area. Int. Comm. Northw. Atlant. Fish., Ann. Proc., 4: 67-102.

HUYER, A., and A. VERNEY. 1975. Temperature, salinity and sigma-t at Station 27, 1950-1959. Mar. Environ. Data Serv. Tech. Rep., 3: 45 p.

ICES. 2001. The annual ICES ocean climate status summary for 2000. International Council for Exploration of the Sea, Palaegade 2-4 DK-1261, Copenhagen K Denmark, 18 p.

ICNAF. 1967. Selected papers from a special meeting of the environmental subcommittee, May 1967, on fluctuations in the sea and air temperature in ICNAF area since 1950. ICNAF Redbook, Part IV, 105 p.

1978. List of ICNAF standard oceanographic sections and stations. ICNAF Sel. Papers, 3: 16 p.

1972. Symposium on environmental conditions in the Northwest Atlantic, 1960-1969. ICNAF area since 1950. ICNAF Spec. Publ., 8: 254 p.

KEELEY, J. R. 1981. Temperature, salinity and sigma-t at Station 27, an analysis of historical data. Mar. Environ. Data Serv. Tech. Rep., 8: 56 p.

LAZIER, J. R. N., and D. G. WRIGHT. 1993. Annual velocity variations in the Labrador Current. J. Phys. Oceanogr., 23: 659-678.

LILLY, G. R., P.A. SHELTON, J. BRATTEY, N.G. CADIGAN, E.R. MURPHY, and D.E. STANSBURY. MS 1999. An assessment of the cod stock in NAFO Divisions $2 \mathrm{~J}+3 \mathrm{KL}$. Can. Stock Assess. Sec. Res. Doc., No. 99/42, 165 p.

MANN, K. H., and K. F. DRINKWATER. 1994. Environmental influence on fish and shellfish production in the Northwest Atlantic. Environ. Rev., 2: 16-32. 
MYERS, R. A., S. A. AKENHEAD, and K. DRINKWATER. 1990. The influence of Hudson Bay runoff and ice-melt on the salinity of the inner Newfoundland Shelf. Atmos.Ocean, 28: 120-157.

MYERS, R.A., K.F. DRINKWATER, N. J. BARROWMAN, and J.W. BAIRD. 1993. Salinity and recruitment of Atlantic cod (Gadus morhua) in the Newfoundland region. Can. J. Fish. Aquat. Sci., 50: 1599-1609.

MYERS, R. A., J. HELBIG, and D. HOLLAND. 1989. Seasonal and interannual variability of the Labrador Current and West Greenland Current. ICES C.M.Doc., No. 1989/C:16, $18 \mathrm{p}$.

NAFO. 1982. Symposium on environmental conditions in the Northwest Atlantic during 1970-1979. NAFO Sci. Coun. Studies, 5: 7-110.

1994. Impact of anomalous oceanographic conditions at the beginning of the 1990s in the Northwest Atlantic on the distribution and behaviour of marine life. Proceedings of NAFO Symposium held in Dartmouth, N.S. in September 1994. NAFO Sci. Coun. Studies, 24: 155 p.

NARAYANAN, S., J. CARSCADDEN, J. B. DEMPSON, M. F. O'CONNELL, S. PRINSENBERG, D. G. REDDIN, and N. SHACKELL. 1994. Marine climate off Newfoundland and its influence on Atlantic salmon (Salmo salar) and capelin (Mallotus villosus). In: Climate Change and Northern Fish Populations. R. J. Beamish (ed.). Can Spec. Publ. Fish. Aquat. Sci., 121: 461-474.

NARAYANAN, S., E. B. COLBOURNE, and C. FITZPATRICK. 1991. Frontal oscillations on the Northeast Newfoundland Shelf, Atmos.-Ocean, 29: 547-562.

PARKINSON, C. L., D. J. CAVALIERI, P. GLOERSEN, H. J. ZWALLY, and J. C. COMISO. 1999. Arctic sea ice extents, areas, and trends, 1978-1996. J. Geophys. Res., 104: 20 837-20 856.

PARSONS, L. S. and W. H. LEAR. 2001. Climate variability and marine ecosystem impacts: a North Atlantic perspective. Prog. Oceanogr., 49: 167-188.

PETERSON, I., 1987. A snapshot of the Labrador Current inferred from ice-flow movement in NOAA satellite imagery. Atmos.-Ocean, 25: 402-415.

PETRIE, B., S. AKENHEAD, J. LAZIER, and J. LODER. 1988. The cold intermediate layer on the Labrador and northeast Newfoundland Shelves, 1978-1986. NAFO Sci. Coun.
Studies, 12: 57-69.

PETRIE, B., and C. ANDERSON. 1983. Circulation on the Newfoundland Shelf. Atmos.-Ocean, 21: 207-226.

PETRIE, B., J. LODER, S. AKENHEAD, and J. LAZIER. 1991. Temperature and salinity variability on the eastern Newfoundland Shelf: the annual harmonic. Atmos.-Ocean, 29: $14-36$.

ROGERS, J. C. 1984. The association between the North Atlantic oscillation and the southern oscillation in the Northern Hemisphere. Mon. Weather Rev., 112: 1999-2105.

ROSE, G. A., B. A. ATKINSON, J. BAIRD, C. A. BISHOP and D. W. KULKA. 1994. Atlantic cod distributional changes and thermal variations in Newfoundland waters, 1980-1992. ICES Mar. Sci. Symp., 198: 542-552.

ROSE, G.A., B. DE YOUNG, and E. COLBOURNE. 1995. Cod (Gadus morhua) migration speeds and transport relative to currents on the Northeast Newfoundland Shelf. ICES J. Mar. Sci., 52: 903-913.

STANSBURY, D.E., P.A. SHELTON, E.F. MURPHY, and J. BRATTEY. MS 1999. An assessment of the cod stock in NAFO Divisions 3NO. NAFO SCR Doc., No. 62, Serial No. N4121, 43 p.

SMITH, E. H., F. M. SOULE, and O. MOSBY. 1937. The Marion and General Green expeditions to Davis Strait and Labrador Sea. Bull. U.S. Coast Guard Bulletin, 19: 259 p.

TAGGART, C., J. ANDERSON, C. BISHOP, E. COLBOURNE, J. HUTCHINGS, G. LILLY, J. MORGAN, E. MURPHY, R. MYERS, G. ROSE, and P. SHELTON. 1994. Overview of cod stocks, biology, and environment on the Northwest Atlantic region of Newfoundland, with emphasis on northern cod. ICES Mar. Sci. Symp., 198: 140-157.

THERRIAULT, J.-C., B. PETRIE, P. PEPIN, J. GAGNON, D. GREGORY, J. HELBIG, A. HERMAN, D. LEFAIVRE, M. MItCHELl, B. PELCHAT, J. RUNGE, and D. SAMEOTO. 1998. Proposal for a Northwest Atlantic zonal monitoring program. Can. Tech. Rep. Hydrogr. Ocean Sci., 194: $57 \mathrm{p}$.

WALSH S. J., M. J. VEITCH, M. J. MORGAN, W. R. BOWERING, and W. B. BRODIE. MS 2000. Distribution and abundance of yellowtail flounder (Limanda ferruginea) on the Grand Bank, NAFO Divisions 3LNO, as derived from annual Canadian bottom trawl surveys. NAFO SCR Doc., No. 35, Serial No. N4264, 54 p. 
